\title{
SELECTION OF TREATMENT METHODS FOR BLEEDING ANEURYSMS
}

\author{
Vesna Nikolov ${ }^{1}$, Boban Jelenković ${ }^{2}$, Marija Andjelković-Apostolovićs ${ }^{3}$ Predrag Milošević ${ }^{1}$
}

\begin{abstract}
Whether to treat bleeding aneurysms surgically or by endovascular occlusion is a frequent subject of debate between neurosurgeons and radiologists.

The aim was to take a general position on when to apply which method through the overview of the results that have been achieved so far. However, each patient must be seen as an individual in order for the right decision to be made.

A prospective study of 336 patients who were treated at the Clinic of Neurosurgery in Niš for a ruptured aneurysm in the period between January 2007 and December 2010 has been conducted. Hunt-Hess grading system was used and the patients who were treated were those with grade I, II and III.

Out of 336 bleeding aneurysms, embolization was used to treat 154 of them, whereas 282 patients underwent operative treatment.

Embolization was a method of choice when dealing with aneurysms in the basilar flow, as well as in the initial segment of the carotid flow.

Better results were obtained in patients treated, either surgically or endovascularly, 72 hours after the bleeding.
\end{abstract}

Acta Medica Medianae 2019;58(3):60-66.

Key words: bleeding aneurysm, endovascular occlusion, clipping aneurysm, embolization, basilar artery, middle cerebral artery

${ }^{1}$ Clinic of Neurology, Clinical Center Niš, Niš, Srbija

2University of Niš, Faculty of Medicine, Niš, Serbia

${ }^{3}$ Public Health Institute, Niš, Srbija

Contact: Vesna Nikolov

Blvd dr Zoran Djindjić 48, 18000 Niš, Serbia

E-mail: v.novak@yahoo.com

\section{Introduction}

A sudden headache followed by nausea and vomiting is usually caused by subarachnoid hemorrhage $(\mathrm{SAH})$ caused by aneurysm rupture on the blood vessels of the brain. Intracranial aneurysms represent localized extensions of structurally altered walls of blood vessels of the brain that, with their rupture, lead to blood flowing into the subarachnoidal area. It may be accompanied by minor hemorrhage "warning laic" or severe intracranial hemorrhage, which is accompanied by loss of conscience and neurological deficits.

CT findings on the brain can show the presence of blood in the subarachnoidal area, intracerebral or intraventricular hemorrhage. The defini- tive confirmation of the presence of an aneurysmal change in the blood vessels of the brain is made by a CT-angio, MR-angio scan and digital subtraction angiography.

Treatment of ruptured intracranial aneurysms continues to be a challenge and requires top technique and working precision of the neurosurgeon.

In addition to operative treatment of aneurysms, the endovascular solution to these changes has also been used recently. The choice of the method of treatment depends on the clinical condition of the patient, CT findings, form and localization of an aneurysm, as well as on the condition on the carrying blood vessel of an aneurysm.

After examining the clinical status of the patient, CT findings of the brain as well as localization of an aneurysm on the blood vessel, a decision is made on how to treat the patient. The use of surgical treatment of bleeding aneurysms or endovascular occlusion is a common topic of discussion between a radiologist and a neurosurgeon. The decision on the method of treatment is made by a neurosurgeon and a neuroradiologist after looking at all the parameters for each patient individually.

\section{Patients and methods}

A prospective study of the 336 patients treated at the Clinic for Neurosurgery in Niš, where aneurysm rupture occurred, ran from January 2015 to December 2017. 
All of the treated patients were diagnosed with SAH, after using brain CT, in 324 cases standard DSA was used, only in 12 cases, CTA was a main diagnostic tool for the diagnosing the location of the bleeding the aneurysm.

In 66 cases (19.64\%) multiple aneurysms were found, but only in 31 (46.99\%) cases we were able to manage operatively or to embolism each of the patient's aneurysms.

According to initial clinical status, we could grade patients using Hunt-Hess scale, and brain CT scan findings determined their Fisher scale.

Patients were in all of the cases initially postoperatively or postembolisation treated in Intensive care unit. All of the patients received antiedematous therapy, analgesics before and after operation or intervention. Embolised patients were on a combination of two antiplatelet medications, after the intervention, as neuroradiologist indicated.

In all of the patients, a CT brain scan control was done according to the protocol of the Clinic. In twelve of them, control DSA was done, due to the clinical signs of the vasospasm or when CTA was not much of the informative significance.

Data were presented in mean \pm standard deviation, and statistical significance was defined as $p$ $<0.001$, in all comparisons. Statistical significance was analyzed with chi-square test for categorical variables and two sample t-tests for continuous variables. Results were presented in tables as numeric value and percentage.

\section{Results}

Out of 336 hemorrhaging aneurysms, 154 were treated with embolization, while in 182 patients were operated. There were 211 (62.80\%) female patients and 135 male (37.20\%). The average age of the treated patients was $52.14 \pm 16.14$.

The existence of highly statistically significant differences in the method of the treatment of an aneurysm by localization was confirmed $\left(\chi^{2}=\right.$ $164.648 ; p<0.001)$. It was found that the aneurysms on the carotid artery and the basilar artery were embolized significantly more often than op- erated on $\left(\chi^{2}=52.927 ; p<0.001\right.$ and $\chi^{2}=61.405$; $\mathrm{p}<0.001$, respectively) (Table 1 ).

There was a significant difference in patient gradation according to the Hunt-Hesse scale relative to the method of treatment of an aneurysm $\left(\chi^{2}=\right.$ $13.51 ; p<0.001)$. Patients of the I stage were embolized more often $\left(\chi^{2}=14.287 ; p<0.001\right)$ while the patients of the III stage were operated on more often $\left(\chi^{2}=21.850 ; p<0.001\right)$ (Table 2$)$.

A significant difference in patient gradation according to the Fisher scale and the method of treatment was determined $\left(\chi^{2}=69.771 ; p<0.001\right)$. Significantly higher number of patients who were in stage II were embolized $\left(\chi^{2}=72.479 ; p<0.001\right)$, while patients in stage III were operated on more often $\left(\chi^{2}=76.576 ; p<0.001\right)$ (Table 3$)$.

There was no difference in treatment dynamics when performing operation when taking into account the localization of an aneurysm $\left(\chi^{2}=5.380\right.$; $p=0.250$ ) (Table 4).

There was no difference in treatment dynamics when performing embolization when taking into account the localization of an aneurysm $\left(\chi^{2}=7.758\right.$; $p=0.170$ ) (Table 5).

The outcome of the patient's treatment showed a significant difference when taking into account the dynamics of the operation $\left(\chi^{2}=9.980 ; \mathrm{p}=\right.$ 0.018 ). A good outcome had a significantly greater number of patients who were operated on after 72 hours $\left(\chi^{2}=6.808 ; p=0.009\right)$, while the neurological deficit was more present in patients who were operated on within 72 hours $\left(\chi^{2}=24.809\right.$; $\mathrm{p}<$ 0.001) (Table 6).

Regarding the outcome of the patient's treatment, it significantly differed in relation to the duration of the implementation of the embolization $\left(\chi^{2}=\right.$ 36.416; $p<0.001$ ). A good outcome had a significantly larger number of patients who were embolized after 72 hours $\left(\chi^{2}=32.046\right.$; $\left.p<0.001\right)$, while the neurological deficit was more present in patients embolized within 72 hours $\left(\chi^{2}=9.394 ; p=0.002\right)$ (Table 7).

Table 1. Localization and method disposing of aneurysm

\begin{tabular}{|c|c|c|c|c|}
\hline Localization of aneurysm & Operatively treated & Embolized & $\chi^{2}$ & $\mathrm{p}$ \\
\hline A. carotis internal & 27 & 80 & & \\
\hline A. comunicans posterior & 10 & 4 & & \\
\hline A. cerebri media & 88 & 9 & 164648 & $<0,001$ \\
\hline A. comunicans anterior & 53 & 11 & 104.040 & -0.001 \\
\hline A. pericalosa & 4 & 5 & & \\
\hline A. basilaris & 0 & 45 & & \\
\hline Total & 182 & 154 & & \\
\hline
\end{tabular}


Table 2. Gradation of patients according to the Hant-Hesse scale

\begin{tabular}{|c||c||c||c||c||}
\hline Gradus & Operated & Embolized & $\chi^{2}$ & $\mathrm{p}$ \\
\hline \hline I & 77 & 97 & & \\
II & 73 & 54 & & \\
III & 32 & 3 & 27.021 & $<0.001$ \\
IV & 0 & 0 & & \\
V & 0 & 0 & & \\
\hline \hline Total & 182 & 154 & & \\
\hline
\end{tabular}

Table 3. Gradation of patients according to the Fissher scale

\begin{tabular}{|c||c||c||c||c||}
\hline Gradus & Operated & Embolized & $\chi^{2}$ & $\mathrm{p}$ \\
\hline \hline I & 0 & 0 & & \\
II & 111 & 152 & 69.771 & $<0.001$ \\
III & 68 & 2 & & \\
IV & 3 & 0 & & \\
\hline \hline Total & 182 & 154 & & \\
\hline
\end{tabular}

Table 4. Time of operational performance

\begin{tabular}{||l||c||c||c||c||c||}
\hline \multicolumn{1}{|c||}{ Localization aneurysm } & $\begin{array}{c}\text { Operated } \\
\text { within 72h }\end{array}$ & $\begin{array}{c}\text { Operated } \\
\text { after 72h }\end{array}$ & Total & $\chi^{2}$ & $p$ \\
\hline \hline A. carotis internal & 10 & 17 & 27 & & \\
A. comunicans posterior & 7 & 3 & 10 & \\
A. cerebri media & 49 & 39 & 88 & 5.380 & 0.250 \\
A. comunicans anterior & 28 & 25 & 53 & \\
A. pericalosa & 1 & 3 & 4 & \\
A. basilaris & 0 & 0 & 0 & \\
\hline \hline \multicolumn{1}{|c|}{ Total } & 95 & 87 & 182 & & \\
\hline \hline
\end{tabular}

Table 5. Time of embolization performance

\begin{tabular}{||l|c||c|c|c||c||}
\hline \multicolumn{1}{|c||}{ Localization aneurysm } & $\begin{array}{c}\text { Embolization } \\
\text { within 72h }\end{array}$ & $\begin{array}{c}\text { Embolization } \\
\text { after 72h }\end{array}$ & Total & $\chi^{2}$ & $\mathrm{p}$ \\
\hline \hline A. carotis internal & 23 & 57 & 80 & & \\
A. comunicans posterior & 1 & 3 & 4 & \\
A. cerebri media & 2 & 7 & 9 & 7.758 & 0.170 \\
A. comunicans anterior & 4 & 7 & 5 & \\
A. pericalosa & 0 & 5 & 45 & \\
A. basilaris & 5 & 40 & 154 & & \\
\hline \hline Total & 35 & 119 & & \\
\hline
\end{tabular}


Tabela 6. Outcome of operatively treated patients

\begin{tabular}{||l|c|c|c||c|c||}
\hline \multicolumn{1}{|c|}{ Outcome of the patient } & $\begin{array}{c}\text { Operated } \\
\text { within 72h }\end{array}$ & $\begin{array}{c}\text { Operated after } \\
72 \mathrm{~h}\end{array}$ & Total & $\chi^{2}$ & $\mathrm{p}$ \\
\hline \hline Good & 71 & 78 & 149 & & \\
Neurological deficit & 10 & 7 & 17 & \\
Vegetative state & 5 & 0 & 5 & 9.980 & 0.018 \\
Deadly & 9 & 2 & 11 & & \\
\hline
\end{tabular}

Table 7. Outcome of embolized patients

\begin{tabular}{|c|c|c|c|c|c|}
\hline Outcome of the patient & $\begin{array}{l}\text { Embolized } \\
\text { within } 72 \mathrm{~h} \\
\end{array}$ & $\begin{array}{l}\text { Embolized } \\
\text { after } 72 \mathrm{~h}\end{array}$ & Total & $x^{2}$ & $\mathrm{p}$ \\
\hline Good & 21 & 114 & 135 & \multirow{4}{*}{36.416} & \multirow{4}{*}{$<0.001$} \\
\hline Neurological deficit & 7 & 5 & 12 & & \\
\hline Vegetative state & 2 & 0 & 2 & & \\
\hline Deadly & 2 & 0 & 5 & & \\
\hline Total & 35 & & & & \\
\hline
\end{tabular}

\section{Discussion}

The annual incidence of the hemorrhage is 6$7 / 100,000$; during the lifetime, $15-20 \%$ of aneurysms bleed and half of the patients are below 55 years of age $(1,2,3,4)$. Recently, two methods for the treatment of hemorrhaging have been used: operational, i.e. clipping of an aneurysm or an endovascular treatment where a detachable coil (5) is applied. The method of treatment depends on the localization of an aneurysm, the CT findings of the brain and angiography, also the general condition of the patients (6).

In our study of a total of 336 bleeding aneurysms, 154 were treated with embolization, while 182 patients were operated on (Table 1 ). The existence of highly statistically significant differences in the method of treatment of an aneurysm by locaiization was found $\left(\chi^{2}=164.648 ; p<0.001\right)$. Aneurysms on the carotid and basilar arteries were embolized more often $\left(\chi^{2}=52.927 ; \mathrm{p}<0.001\right.$ and $\chi^{2}=$ $61.405 ; p<0.001$, respectably). Many years of experience have shown that the aneurysms on the carotid artery, especially in the initial part, as well as on the basilar artery, are difficult to reach through surgery. Also, aneurysms solved by surgery, especially in the basilar portion of Wilson's hexagon, had a poor postoperative course. The introduction of endovascular techniques in the treatment of these aneurysms gave far better results. Molyneux et al. showed similar results in their studies $(7,8)$.

The choice of the method of treatment was influenced by the condition of the patient gradated by the Hunt-Hesse scale (Table 2), as well as the CT findings of the brain classified by using the Fisher scale (Table 3). The importance of clinical status, management, and monitoring of patients with subarachnoidal hemorrhage were demonstrated by Sodhi in his study (9). Namely, there is a significant difference in patient gradation according to the Hunt -Hesse scale in relation to the method of treatment of an aneurysm $\left(\chi^{2}=13.51 ; p<0.001\right)$. Patients in the stage I were often embolized $\left(\chi^{2}=14.287\right.$; $p<$ 0.001 ) while patients in the stage III were operated more often $\left(\chi^{2}=21.850 ; p<0.001\right)$. The general condition of the patients depends in large part on the CT findings of the brain, thus determining that there is a significant influence of the Fisher scale in relation to the method of treatment of an aneurysm $\left(\chi^{2}=69.771 ; p<0.001\right)$. A significantly larger number of patients who were in the stage II were embolized $\left(\chi^{2}=72.479 ; p<0.001\right)$, while stage III patients are more frequently operated on $\left(\chi^{2}=\right.$ 76.576; $p<0.001)$. Subgroup analysis in the study of $\mathrm{Li}$ et al (5) showed that embolization yielded better results in patients who had a good clinical status prior to the intervention. In the stage III of the Fisher scale, intracerebral hematoma was present, which could only be extracted through surgery, which explains the choice of the applied treatment method (10).

The duration of treatment of bleeding depends on the general condition of the patient, the CT findings of the brain and the angiographic findings as well. The duration of treatment of the patients largely depends on the presence of vasospasm in 
the blood vessels. Certain authors divide the first week after the hemorrhage into two separate periods: from day zero (the day of hemorrhage) to 2 days (48 hours after the hemorrhage) and a period of 3 to 7 days when the vasospasm is observed (11, $12,13,14)$. Angiographically verified vasospasm is rare in the first two days after the hemorrhage, and its incidence rises after the fourth day (15).

In our study, no significant statistical difference was found when comparing the dynamics of treatment of the aneurysms and its localization (Table 4 and 5), unlike its comparation with outcome. In both the embolized patients and those operated on, much better results were achieved with interventions done after 72 hours.

A good outcome had a significantly greater number of patients who were operated on after 72 hours $\left(\chi^{2}=6.808 ; p=0.009\right)$, while the neurological deficit was more present in patients who were operated on within 72 hours $\left(\chi^{2}=24.809\right.$; $p<$ 0.001 ) (Table 6). In embolised patients, those who were coiled after $72 \mathrm{~h}$ have had good outcomes $\left(\chi^{2}=\right.$ 32.046; $p<0.001$ ), while the neurological deficit was more present in patients operated on within 72 hours $\left(\chi^{2}=9.394 ; p=0.002\right)($ Table 7$)$.

Some authors consider that it is best for the intervention to be done within $72 \mathrm{~h}$ of the bleeding because there are no spasms of blood vessels. Although accumulated evidence suggests that (16) arterial narrowing is not the only cause of clinical deterioration (17), but just a part of a comprehensive change and the impact of multiple factors (18). Our study also confirms that a better result is achieved in people treated after $72 \mathrm{~h}$ from the primary act of hemorrhage. These facts should lead to research for a more comprehensive and more adequate theory that will not only explain the observed disagreements but also lead to the development of a specific and effective treatment strategy.

A higher percentage of fatal outcomes (9.09\%) in patients treated with surgery is explained by the fact that patients treated this way were in the $3^{\text {rd }}$ and $4^{\text {th }}$ stage on the Fisher scale, which means that their preoperative condition was even worse than those of patients in the $1^{\text {st }}$ and $2^{\text {nd }}$ stages.

\section{Conclusion}

Patients whose CT findings of the brain belonged to the $3^{\text {rd }}$ and $4^{\text {th }}$ stage by Fisher's scale were treated using an operative method.

The decision on the treatment method is based on the clinical condition of the patient, CT findings of the brain, angiography findings, and localization of aneurysmal changes.

The application of endovascular occlusion has shown to be the method of choice for the treatment of aneurysms in the basilar basin as well as those of the initial segment of the carotid.

Better results were obtained in patients treated either surgically or endovascularly, 72 hours after the bleeding.

\section{References}

1. Anderson CS. The ACROSS group: Epidemiology of aneurysmal subarachnoid hemorrhage in Australia and New Zealand: incidence and case fatality from the Australasian Cooperative Research on Subarachnoid Hemorrhage Study (ACROSS). Stroke 2000; 31:184350. [PubMed] [CrossRef]

2. de Rooij NK, Linn FH, van der Plas JA, Algra A, Rinkel GJ. Incidence of subarachnoid hemorrhage: a systematic review with emphasis on region, age, gender and time trends. J Neurol Neurosurg Psychiatry 2007; 78:1365-72. [PubMed] [CrossRef]

3. Thrift AG, Dewey HM, Sturm JW, Srikanth VK, Gilligan $\mathrm{AK}$, Gall SI, et al. Incidence of stroke subtypes in the North East Melbourne Stroke Incidence Study (NEMESIS): differences between men and women. Neuroepidemiology 2009; 32:11-8.

[PubMed] [CrossRef] 
4. Van GJ, Kerr RS, Rinkel GJ. Subarachnoid hemorrhage. Lancet 2007; 369:306-18. [PubMed] [CrossRef]

5. Li $H$, Pan $R$, Wang $H$, Rong $X$, Yin Z, Milgrom DP, et al. Clipping versus coiling for ruptured intracranial aneurysms: a systematic review and meta-analysis. Stroke 2013; 44:29-37. [PubMed] [CrossRef]

6. Priebe $\mathrm{HJ}$. Aneurysmal subarachnoid hemorrhage and the anesthetist. $\mathrm{Br}$ J Anaesth 2007; 99:102-18.

[PubMed] [CrossRef]

7. Molyneux A, Kerr R, International Subarachnoid Aneurysm Trial (ISAT) Collaborative Group, Stratton I, Sandercock $P$, Clarke $M$, et al. International Subarahnoidal Aneurysm Trial (IAST) of neurosurgical clipping versus endovascular coiling in 2143 patients with ruptured intracranial aneurysma:a randomized trial. Lancet 2002; 360:1267-74. [CrossRef]

8. Molyneux AJ, Kerr RS, Yu LM, Clarke M, Sneade M, Yarnold $\mathrm{JA}$, et al. Inetrnational subarahnoidal aneurisam trial (ISAT) of neurosurgical clipping versus endovascular coiling in 2143 patientes with ruptured intracranial aneurysmas:a randomized comparation of effects on survival, dependency, seizure, rebleeding, subgroups and aneurysm occlusion. Lancet 2005; 366 (9488):809-17. [PubMed] [CrossRef]

9. Sodhi HB, Savardekar A, Mohindra S, Chhabra R, Gupta V, Gupta SK. The clinical profile, management, and overall outcome of aneurysmal subarachnoid hemorrhage at the neurosurgical unit of a tertiary care center in India. J Neurosci Rural Pract 2014;5:118-26. [PubMed] [CrossRef]

10. Seifert V, Loffler B, Zimmermann M, Roux S, Stolke D, et al. Endothelin concentrations in patients with aneurysmal subarachnoid hemorrhage: Correlation with cerebral vasospasm, delayed ischemic neurological deficits and volume of hematoma. J Neurosurg 1995; 82(1):55-62. [PubMed] [CrossRef]

11. Weir B, Grace M, Hansen J, Rothberg C. Time course of vasospasm in man. J Neurosurg 1978; 48(2):1738. [PubMed] [CrossRef]

12. Harrigan MR. Intracranial Aneurysms and Subarachnoid Hemorrhage. In: Harrigan MR, Deveikis JP, editors. Handbook of Cerebrovascular Disease and Neurointerventional Technique. New York: Humana Press; 2018. p. 601-711.

13. Russin JJ, Montagne A, D'Amore F, He S, Shiroishi MS, Rennert RC, et al. Permeability imaging as a predictor of delayed cerebral ischemia after aneurysmal subarachnoid hemorrhage. J Cereb Blood Flow Metab 2018; 38(6):973-9. [PubMed] [CrossRef]

14. de Oliveira Manoel AL, Macdonald RL. Neuroinflammation as a Target for Intervention in Subarachnoid Hemorrhage. Front Neurol 2018; 9:292. [PubMed] [CrossRef]

15. Singh J, Wicks RT, Wilson JA, Wolfe SQ, Fargen KM. Radiographic Vasospasm and Clinical (Symptomatic).2018; Vasospasm. Intracranial Aneurysms, 161-1.

16. Clarke E. Apoplexy in the Hippocratic writings. Bull Hist Med 1963; 37:301.

17. Burnett M, Danish S, McKhann G, II. Pathology and pathophysiology of aneurysmal subarachnoid hemorrhage. In: Leroux $\mathrm{P}$, Winn W, Newell D, editors. Management of Cerebral Aneurysms. Philadelphia, PA: Elsevier; 2004. p. 127-37.

18. Kassell NF, Torner JC, Haley EC Jr, Jane JA, Adams $\mathrm{HP}$, Kongable GL. The International Cooperative Study on the Timing of Aneurysm Surgery. Part 1: Overall management results. J Neurosurg. 1990;73(1):18-36. [PubMed] [CrossRef] 


\title{
IZBOR METODE LEČENJA KRVAREĆIH ANEURIZMI
}

\author{
Vesna Nikolov ${ }^{1}$, Boban Jelenković ${ }^{2}$, Marija Anđelković-Apostolović3 ${ }^{3}$ Predrag Milošević ${ }^{1}$
}

\author{
${ }^{1}$ Klinika za neurohirurgiju Klinički centar Niš, Niš, Srbija \\ ${ }^{2}$ Univerzitet u Nišu, Medicinski fakultet, Niš, Srbija \\ ${ }^{3}$ Institut za javno zdravlje Niš, Niš, Srbija \\ Kontakt: Vesna Nikolov \\ Bulevar dr Zorana Đinđića 48, 18000 Niš, Srbija \\ E-mail: v.novak@yahoo.com
}

Primena operativnog lečenja krvarećih aneurizmi ili endovaskularana okluzija, česta je tema diskusije između radiologa i neurohirurga.

Cilj rada bio je da se sagledavanjem dosadašnjih rezultata okvirno zauzme stav kada koju metodu treba primeniti. Mada, uvek je bitno svakog bolesnika sagledati ponaosob u cilju donošenja prave odluke.

Vršena je prospektivna studija bolesnika lečenih na NHK u Nišu, kod kojih je došlo do rupture aneurizme, u periodu od januara 2015. do decembra 2017. godine. Korišćena je skala gradacije po Hant-Hessu i tretirani su bolesnici iz I, II i III gradusa.

Od ukupno 336 krvarećih aneurizmi, kod 154 pristupilo se embolizaciji, dok je kod 182 bolesnika primenjeno operativno lečenje.

Primena embolizacije pokazala se kao metoda izbora pri rešavanju aneurizmi u bazilarnom slivu, kao i na početnom segmentu karotidnog sliva.

Bolji rezultati dobijeni su kod bolesnika tretiranih bilo operativno ili endovaskularno, nakon $72 \mathrm{~h}$ od hemoragije.

Acta Medica Medianae 2019;58(3):60-66.

Ključne reči: krvareće aneurizme, endovaskularna okluzija, klipovanje aneurizme, bazilarna arterija, srednja cerebralna arterija 